\title{
COMMUNITY INVOLVEMENT IN SELECTIVE WASTE COLLECTION AND RECOVERY PROGRAMS
}

\author{
Corina GRIGORE (SLABU) ${ }^{a}$, Madlena NEN \\ ${ }^{a}$ Bucharest University of Economic Studies, Romania \\ ${ }^{b}$ Military Technical Academy in Bucharest, Romania
}

\begin{abstract}
The paper summarizes the main strategies for increasing community involvement and mobilizing citizens in waste collection and recovery programs both nationally and globally, in the context of a sustainable economy. Structured in two directions, this study begins with the presentation of general considerations related to the need to involve the local community in integrated waste management. Finally, the major goal is highlighted, namely the selective collection of waste for recycling, resulting in the conservation of natural resources and a cleaner environment. The role that the research must play in developing new solutions in this regard is also emphasized.
\end{abstract}

KEYWORDS: solid waste, collection, recycling, strategy

\section{INTRODUCTION}

The waste is a pressing issue, both globally and locally, which has become a priority in public policy. Waste has a high potential for environmental pollution, gaining a global dimension. Improper waste management generates public health risks as well as short and long term costs.

The increase in the consumption of goods in the last period has also had the effect of increasing the volume of waste generated by the population. For this reason, the environment has suffered, with climate change, one of the main causes being inadequate waste management.

Thus, it is necessary to take measures to reduce the amount of waste deposited in landfills for disposal, and thus increase the amount of recyclable waste extracted from municipal waste, therefore involving the community in selective waste collection and recovery programs is needed, having an essential role in this regard.

Selective collection, as defined in Wikipedia (Colectare selective, n.d.), represents a part of the recycling process, through which recyclable materials are collected and transported to recycling centers. The recycling process involves composting waste, separate collection and waste treatment for their reintroduction into economic circuit."

„The relations that are established between man and nature depend to a large extent on the applied economic circuit. To overcome or alleviate the problems within this relationship, the classical economic model or "linear" model, based on the principle of "resource consumption - product waste" should be gradually replaced through the "circular" model, which presupposes the principle "resource consumption - product - waste recovery which becomes a secondary resource" (Tुurcan, 2019).

Under these conditions, proper waste management is a basic pillar of long-term policies aimed at sustainable development, minimizing the amount of waste generated and recycling it as a priority.

\footnotetext{
* Corresponding author. E-mail address: grigorecristicorina@yahoo.com
} 


\section{METHODOLOGY APPLIED}

The working methodology adopted for the presentation of the study was chosen in order to be able to formulate answers to the questions:

- What is the situation regarding the generation of solid waste in Romania?

- What are the main factors involved and what role does it play?

- What is the level of involvement and mobilization of the population in the process of selective collection of solid waste?

The research methodology for the elaboration of the works includes two stages:

o The documentation stage, which consisted in collecting and analyzing studies, data and reports submitted by various institutions in connection with the degree of selective collection of waste generated and identifying good practices at European level on mobilizing the population in this regard;

o The stage of formulating some public policy recommendations by unitarily adopting strategies at national level in which all the factors involved to act synergistically.

\section{RESULTS}

Lately, in the conditions of increasing global consumption, the volume of waste generated has increased exponentially, requiring measures to act on two levels: waste generation and recycling. According to a final report of the European Union (European Commission, DG Environment, Analysis of the evolution of waste reduction and the scope of waste prevention - Final report, 2010 https://ec.europa.eu/environment/waste/prevention/pdf/report_waste.pdf), in the period 2006-2020, an increase in the amount of household waste in EU member states was forecast by about $40 \mathrm{~kg} /$ place.

According to statistics published on Statistics Explained, official website of Eurostat (from https://ec.europa.eu/eurostat/statistics-explained/index.php?title=Waste_statistics/ro ), in 2016, the following were recorded:

- 5 tons of waste per capita were generated in the EU;

- $45.7 \%$ of the waste was dumped in landfills and $37.8 \%$ was recycled;

- total waste generated in EU-28 of all economic and household activities amounted to 2,538 million tons.

The study also shows that "the total volume of waste generated is related to a certain extent to the size of the population and the economic size of a country. In Table 1, the smallest EU Member States generally reported the lowest levels of waste generation, and the highest, the highest levels. However, relatively large amounts of waste were generated in Bulgaria and Romania, and in Italy, a relatively small amount.

Figure 1 shows the share of different economic activities and households in the total waste generated in 2016. At EU-28 level, in 2016, constructions contributed $36.4 \%$ of the total, followed by the extractive industry $(25.3 \%)$, the manufacturing industry $(10.3 \%)$, water and waste $(10 \%)$ and households $(8.5 \%)$; the remaining $9.5 \%$ was waste generated by other economic activities, especially services (4.6\%) and energy (3.1\%).

According to statistics, in 2016, approximately 2,312 million tons of waste were treated in the EU-28. 
Table 1.Waste generation by economic activities and households, 2016 (\%)

Waste generation by economic activities and households, 2016

$(\%)$

\begin{tabular}{|c|c|c|c|c|c|c|}
\hline & Mining and quarrying & Manufacturing & Energy & $\begin{array}{c}\text { Construction and } \\
\text { demolition }\end{array}$ & $\begin{array}{c}\text { Other economic } \\
\text { activities }\end{array}$ & Households \\
\hline EU-28 & 25 & 10 & 3 & 36 & 16 & 8 \\
\hline Belgium & 0 & 23 & 1 & 31 & 36 & 8 \\
\hline Bulgaria & 82 & 3 & 8 & 2 & 3 & 2 \\
\hline Czechia & 1 & 18 & 4 & 40 & 23 & 14 \\
\hline Denmark & 0 & 5 & 4 & 58 & 16 & 17 \\
\hline Germany & 2 & 14 & 3 & 55 & 17 & 9 \\
\hline Estonia & 26 & 37 & 25 & 5 & 6 & 2 \\
\hline Ireland & 16 & 35 & 2 & 10 & 28 & 10 \\
\hline Greece & 78 & 6 & 4 & 1 & 4 & 7 \\
\hline Spain & 16 & 11 & 3 & 28 & 26 & 17 \\
\hline France & 1 & 7 & 0 & 69 & 14 & 9 \\
\hline Croatia & 12 & 8 & 2 & 24 & 31 & 22 \\
\hline Italy & 0 & 17 & 2 & 33 & 29 & 18 \\
\hline Cyprus & 5 & 33 & 0 & 36 & 10 & 16 \\
\hline Latvia & 0 & 19 & 11 & 4 & 30 & 34 \\
\hline Lithuania & 1 & 41 & 2 & 8 & 32 & 17 \\
\hline Luxembourg & 0 & 7 & 0 & 75 & 11 & 6 \\
\hline Hungary & 1 & 17 & 16 & 23 & 25 & 18 \\
\hline Malta & 8 & 1 & 0 & 69 & 13 & 8 \\
\hline Netherlands & 0 & 10 & 1 & 70 & 13 & 6 \\
\hline Austria & 0 & 9 & 1 & 73 & 10 & 7 \\
\hline Poland & 39 & 17 & 11 & 10 & 18 & 5 \\
\hline Portugal & 3 & 17 & 1 & 12 & 35 & 33 \\
\hline Romania & 87 & 4 & 4 & 0 & 3 & 2 \\
\hline Slovenia & 0 & 26 & 14 & 10 & 38 & 12 \\
\hline Slovakia & 3 & 32 & 9 & 9 & 29 & 18 \\
\hline Finland & 76 & 8 & 1 & 11 & 3 & 1 \\
\hline Sweden & 77 & 4 & 1 & 7 & 7 & 3 \\
\hline United Kingdom & 6 & 4 & 0 & 49 & 30 & 10 \\
\hline Iceland & 0 & 25 & 0 & 4 & 31 & 40 \\
\hline Liechtenstein & 3 & 2 & 0 & 88 & 1 & 5 \\
\hline Norway & 3 & 14 & 2 & 27 & 32 & 22 \\
\hline Montenegro & 19 & 2 & 18 & 37 & 10 & 13 \\
\hline North Macedonia & 49 & 51 & 0 & 0 & 0 & 0 \\
\hline Serbia & 79 & 3 & 12 & 1 & 2 & 3 \\
\hline Turkey & 11 & & 26 & 1 & $:$ & 37 \\
\hline Bosnia and Herzegovina (') & 2 & 27 & 71 & 0 & 0 & 0 \\
\hline Kosovo $\left({ }^{2}\right)$ & 14 & 20 & 40 & 6 & 10 & 11 \\
\hline
\end{tabular}

(') 2012 .

(2) This designation is without prejudice to positions on status, and is in line with UNSCR 1244/1999 and the ICJ Opinion on the Kosovo declaration of independence. Source: Eurostat (online data code: env_wasgen)

Source: Eurostat (Env_wasgen), 2020

Thus, just over half (53.2\%) of waste was treated through recovery operations: recycling (37.8\% of total treated waste), backfilling $(9.9 \%)$ or energy recovery $(5.6 \%)$. The remaining $46.8 \%$ were either deposited in landfills $(38.8 \%)$ or incinerated without energy recovery $(1.0 \%)$ or otherwise disposed of (7.0\%). Significant differences were observed between EU Member States regarding the use of different treatment methods. For example, some Member States had very high recycling rates (Italy and Belgium), while others promoted the use of landfills (Greece, Bulgaria, Romania, Greece, Finland and Sweden) (see 2). 
Table 2. Waste treatment, 2016 (\% of total)

Waste treatment, 2016

(\% of total)

\begin{tabular}{|c|c|c|c|c|c|}
\hline & \multicolumn{3}{|c|}{ Recovery } & \multicolumn{2}{|c|}{ Disposal } \\
\hline & Recycling & Backfilling & Energy recovery & Landfill and other & $\begin{array}{l}\text { Incineration without } \\
\text { energy recovery }\end{array}$ \\
\hline EU-28 & 37.8 & 9.9 & 5.6 & 45.7 & 1.0 \\
\hline Belgium & 76.9 & 0.0 & 12.6 & 6.4 & 4.1 \\
\hline Bulgaria & 5.2 & 0.0 & 0.4 & 94.4 & 0.0 \\
\hline Czechia & 49.5 & 29.0 & 4.5 & 16.6 & 0.4 \\
\hline Denmark & 51.4 & 0.0 & 19.5 & 29.1 & 0.0 \\
\hline Germany & 42.7 & 26.6 & 11.3 & 18.1 & 1.2 \\
\hline Estonia & 21.6 & 11.2 & 2.5 & 64.7 & 0.0 \\
\hline Ireland & 10.6 & 46.0 & 4.8 & 38.4 & 0.3 \\
\hline Greece & 4.8 & 0.0 & 0.3 & 94.8 & 0.0 \\
\hline Spain & 37.1 & 5.7 & 3.6 & 53.6 & 0.0 \\
\hline France & 55.0 & 10.3 & 5.4 & 27.6 & 1.6 \\
\hline Croatia & 47.2 & 4.0 & 1.0 & 47.8 & 0.0 \\
\hline Italy & 78.9 & 0.1 & 4.0 & 14.2 & 2.7 \\
\hline Cyprus & 10.4 & 28.0 & 3.8 & 57.8 & 0.0 \\
\hline Latvia & 71.7 & 1.1 & 6.8 & 20.3 & 0.0 \\
\hline Lithuania & 33.4 & 4.1 & 5.8 & 56.6 & 0.0 \\
\hline Luxembourg & 34.8 & 24.2 & 2.1 & 39.0 & 0.0 \\
\hline Hungary & 54.1 & 3.7 & 7.4 & 34.2 & 0.6 \\
\hline Malta & 19.1 & 63.4 & 0.0 & 17.2 & 0.4 \\
\hline Netherlands & 45.6 & 0.0 & 7.6 & 46.0 & 0.9 \\
\hline Austria & 37.0 & 11.0 & & 45.9 & \\
\hline Poland & 46.2 & 22.2 & 3.3 & 28.0 & 0.4 \\
\hline Portugal & 43.5 & 9.5 & 12.1 & 34.7 & 0.2 \\
\hline Romania & 4.0 & 0.4 & 1.4 & 94.1 & 0.1 \\
\hline Slovenia & 60.2 & 27.2 & 4.8 & 6.9 & 0.8 \\
\hline Slovakia & 40.0 & 4.7 & 7.0 & 47.8 & 0.5 \\
\hline Finland & 7.4 & 0.0 & 4.5 & 88.0 & 0.0 \\
\hline Sweden & 12.0 & 4.9 & 6.6 & 76.3 & 0.2 \\
\hline United Kingdom & 48.5 & 7.8 & 3.4 & 37.5 & 2.7 \\
\hline Iceland & 25.0 & 51.0 & 0.4 & 22.3 & 1.3 \\
\hline Norway & 43.5 & 2.6 & 34.0 & 19.5 & 0.5 \\
\hline Montenegro & 0.8 & 0.0 & 0.2 & 98.9 & 0.0 \\
\hline Serbia & 2.8 & 0.8 & 0.2 & 96.3 & 0.0 \\
\hline Turkey & 33.0 & 0.0 & 0.8 & : & 0.2 \\
\hline Kosovo (') & 0.0 & 0.0 & 0.0 & 100.0 & 0.0 \\
\hline
\end{tabular}

(1) This designation is without prejudice to positions on status, and is in line with UNSCR $1244 / 1999$ and the ICJ Opinion on the Kosovo declaration of independence.

Source: Eurostat (online data code: env_wastrt)

\section{eurostat?}

Source: Eurostat (Env_wasgen), 2020

Compared to 2016, according to data taken from Eurostat, "Romania generated 272 tons of municipal waste per person in 2018, this being the lowest amount in the European Union, according to a report by Eurostat - Statistical Office of the European Union. According to the study, in the European Community, the amount of municipal waste generated by each person in 2018 amounted to $492 \mathrm{~kg}$, down by $5 \%$ compared to the peak of $518 \mathrm{~kg}$ per person in 2008. In total, 220 million tons of municipal waste were generated in the EU in 2018 and, although the amount generated was higher than in 2017 (218 million tons), it decreased compared to 2008 (227 million tons). On the other hand, according to Eurostat, the amount of recycled waste reached new levels in 2018, both for recycling materials and for composting.

The recycling of materials has increased to 67 million tons, which corresponds to $150 \mathrm{~kg}$ per person. This was almost three times higher than the 23 million tons (54 $\mathrm{kg}$ per person) recycled in 1995. Accordingly, 37 million tons ( $84 \mathrm{~kg}$ per person) of waste was composted in 2018 , by more than two and a half times more than in 1995 (14 million tons or $33 \mathrm{~kg}$ per person). " (Ciocotisan, 2020).

Regarding the management of packaging waste, "the composition of the waste is worrying. In 2009, about $42 \%$ of the waste was composed of PET, beverage glass packaging and aluminum cans. In 2010, beverage packaging was also the majority, both in terms of volume and weight (excluding construction and demolition waste), although the methodology had changed. 
Beverage packaging accounted for $23.5 \%$ of the total waste composition and $33.57 \%$ by weight." (Teodor et al., 2020).

Moreover, as stated on the official website of the European Union, according to the European strategy on plastics, "all plastic packaging on the EU market will become recyclable by 2030, reducing the consumption of disposable plastic items." (European Commission, Reprezentanţa în România, 2018).

At national level, starting with 2008, Romania has in force the National Strategy for Sustainable Development of Romania Horizons 2013-2020-2030 (Ministry of Environment and Sustainable Development, 2008). In this strategic document, reference is made to the objective of "promoting sustainable consumption and production practices". For 2020, the national objective of sustainable development is to "achieve the current average level of EU countries at the main parameters of responsible management of natural resources".

According to the commitments made before the European Commission, Romania must take all necessary measures to implement economic instruments to help achieve the targets for recycling and reducing the amount of waste deposited in landfills, targets set by European Union law and agreed as objectives of Romania. These economic instruments are very important for the modernization of waste management in Romania, but also for the implementation of European legislation in the field. In this regard, the Emergency Ordinance 74 of July 2018 was adopted, which established a series of obligations of local public administration authorities, including ensuring separate collection for at least paper, metal, plastic and glass waste from municipal waste and reach, by 31 December 2020, a level of readiness for reuse and recycling of at least $50 \%$ of the total mass generated, at least for paper, metal, plastic and glass waste from household waste or, where appropriate, from other sources, insofar as these waste streams are similar to household waste.

According to a communication from the European Commission to the European Parliament, almost "all Member States are encouraged to implement new measures aimed at abandoning the incineration and storage of reusable and recyclable waste and improving and expanding their selective collection systems". As examples of good practice, with regard to the measures adopted, the following countries are nominated:

- „Slovenia illustrates that circular economic policies and improved waste management can be achieved in a short period of time. A comprehensive circularity strategy has stimulated selective collection and recycling, with the help of EU funds;

- Denmark provides a good example of open cooperation along value chains and innovation to promote the circular economy. The percentage of SMEs offering green products or services is significantly higher than the EU average;

- France adopted an ambitious roadmap for the circular economy in 2018, with actions aimed at reducing resource use by $30 \%$ by 2030 . It introduced an ambitious $100 \%$ recycling target for plastics by 2025 , with an estimate of the creation of 300,000 new green jobs. (The European Commission, 2019).

As also shown in the publication Perspectives of Circular Economy in Romanian Space, the European legislative package "Circular Economy" included a series of measures, which Romania must implement:

- Introduction of mandatory recycling rates for different categories of waste, subsequently cascading, based on obligations - Extended responsibility of the producer, companies that place on the market goods that subsequently result in waste; For example, plastic, glass, metal, paper and cardboard waste, as well as biodegradable waste, will no longer be accepted for final disposal;

- Introducing the obligation to redesign the products with two objectives: a) increasing the proportion of recycled raw materials in the total raw materials used by companies; and $b$ ) increasing the recyclability of products at the end of their life cycle, while rewriting the European Waste Code to reconsider some waste as secondary raw materials; 
- Adoption of economic instruments to promote the reuse and stimulation of industrial symbiosis and greener products;

- Increasing the recycling rate of municipal waste to at least $65 \%$ by 2030 ;

- Increase the recycling rate of packaging waste to a minimum of $75 \%$ by 2030 .

(Vermeșan et al.,2020).

Under these conditions, proper waste management is a basic pillar of long-term policies aimed at sustainable development, minimizing the amount of waste generated and recycling it as a priority. An important role in this mechanism is played by the community, which can be determined and sensitized through a series of public policies and local strategies, to contribute to maintaining a clean environment. In this regard, action should be taken on two levels, one related to educating and raising public awareness of the measures it can take, and another related to the establishment of selective collection obligations.

The education and mobilization of the population is of particular importance in an integrated waste management system.

Reduced community involvement, as a waste generator in selective collection programs, it can be determined by the following factors:

$>$ Insufficient ecological education;

$>$ There is no systemic approach at national level to public information campaigns on waste management;

Insufficient involvement of the population in public debates and lack of initiative.

For the successful implementation of waste management measures, an indispensable premise is the acceptance and collaboration of public opinion.

Communication between authorities, sanitation operators, and citizens as waste producers is indispensable.

In order to achieve the objectives of waste management, it is necessary to take measures as follows:

- Information and awareness campaigns as an important tool in environmental education, needed to understand environmental issues;

- Involvement of the population representing an important process in integrated waste management, in that it can lead to decision making accepted by the parties, communication being essential for obtaining positive results.

An information campaign on the importance of selective collection contributes to the successful implementation of what was originally planned. In order to achieve the proposed objectives, they need to be realistic, achievable.

The information and awareness campaigns for the population aim at:

Sustainable and efficient management of natural resources;

$>$ Reducing health problems caused by poor waste management;

$>$ Observance and understanding of the legislation in the field and implicitly its observance;

$>$ Increased understanding of the waste management process, especially related to waste reduction and recycling.

Information campaigns target a rather heterogeneous category, with actions targeting target groups.

The largest waste-generating group is private households. Thus, the best possible communication is needed, mainly aimed at educating on waste management issues.

Population, as consumers as well as waste generators, must know information related to:

$>$ the possibilities of decreasing the volume of waste generated;

the possibilities of selective waste collection;

recycling possibilities.

At national level, the possibilities for selective waste collection are limited, a pressing issue being the provision of a separate collection system on the four types of waste: household, paper, glass and plastic, which has become mandatory since 1 July 2019. In this regard, the sanitation companies 
have the obligation to equip the waste collection points with the four containers for the four types of fractions as well as to ensure their differentiated transport to the landfills. Thus, a permanent collaboration is required between the three main actors: the population, local authorities and sanitation operators, which play a decisive role in the integrated waste management process. It is important for local authorities to understand this concept in order to make correct, informed decisions.

In order to determine the factors involved to comply with the regulations established by the normative acts related to the selective collection, the legislator instituted a series of economic measures and instruments to help Romania reach the waste recycling targets set by European Union legislation and agreed as objectives of Romania, among which we mention:

- "pay as much as you throw", this concept was used to raise awareness and motivate the wastegenerating population, the local public authorities having the obligation to apply this system, starting with January 1, 2019; thus, differentiated tariffs will be introduced for residual waste and recyclable waste, with the collection tariff for recyclable waste being lower than that for residual waste;

- establishing sanctions for non-compliance with the regulations related to selective collection, applicable to both sanitation companies and citizens.

Regarding the strategies adopted at national level related to motivating citizens as waste generators, to collect selectively and to recycle, it is found that the initiatives taken are few, the only actors involved in this process being from the private sector.

Thus, several hypermarket chains have adopted programs that encourage their customers to recycle plastic waste, offering in return certain benefits: goods, money, discount coupons, etc.

It should be mentioned that, in this regard, Romania has large gaps compared to many other states of the European Union, where the involvement of all factors is high, the methods of motivating the community being extremely diverse. As an example, according to a study on Innovative Recycling Methods in a World where selective waste collection is a problem, "Rome residents can pay for their subway ticket with recyclable bins. Special jukeboxes have been made available to travellers to encourage citizens to collect waste separately in order to recycle it as efficiently as possible. More than 350,000 bins were collected by the beginning of this month using this waste collection method. Plastic bottles must be inserted one by one into specially designed vending machines, which can currently be found in three of Rome's metro stations. The vending machines flatten and count the number of spots to provide the appropriate credit. For a subway trip, an Italian has to recycle 30 plastic bottles. Similar initiatives to encourage recycling have also been found in Surabaya, Indonesia's second largest city. Here, the passengers can offer both plastic bottle and cups in exchange for a bus ride. Similarly, the people of the English city of Leeds benefited last year from a program in which they could pay the parking fee by recycling plastic bottles." (Ripeanu, 2019)

\section{CONCLUSIONS}

Waste is a problem of great importance globally and nationally, so it is necessary to implement the most appropriate management in this regard.

Improper waste management in Romania is reflected in the pollution of public spaces with waste, garbage becoming more and more visible.

Preventing waste generation as much as possible, using waste generated as a resource and minimizing the volume of waste that reaches landfills are global priorities. An essential role in this process is played by the community, which is the main waste-generating group. Thus, the selective collection of waste for recycling, as part of the integrated waste management process is a major goal, for the implementation of which strategies have been developed, both globally and locally. 
The application of this concept can be viewed from several points of view, namely:

$>$ Social, by changing the mentality, attitude and behaviour of the community towards the environment, civic responsibility being necessary;

- Economic, because improper waste management generates additional costs;

Ecological, by conserving natural resources and improving environmental conditions.

In order to improve the environmental conditions, a complex of correlated actions is needed in a judicious and realistic way, which involves the development of an adequate community mentality, by increasing civic responsibility, in order to transmit to future generations a healthier environment. In this regard, increasing community involvement and mobilizing citizens in both national and global waste collection and recovery programs is essential in the context of a sustainable economy. In order to fulfill the commitments made before the European Commission, Romania must take all necessary measures to implement economic instruments to help achieve the targets for recycling and reducing the amount of waste deposited in landfills, targets set by European Union law and agreed as objectives of Romania.

Currently, at national level, the degree of selective waste collection is relatively low, having as main causes:

$>$ The low involvement of the population in the process of separate waste collection, by the fact that some consumers are not willing to sort their waste generated from their own households;

$>$ The infrastructure for the selective collection of waste is not created, both in terms of its storage by providing separate collection spaces and containers on the four types of recyclable waste, and related to ensuring the transport with appropriate means of transport;

Reduced involvement of local public authorities and sanitation operators on the development of education and awareness programs for the population, in order to selectively collect solid waste.

In order to solve the problems related to the selective collection of waste for processing, and implicitly to achieve the targets agreed and assumed by Romania harmonized with European Union legislation, it is necessary the involvement and cohesion of all stakeholders: authorities, sanitation and community, public policies having an extremely important role in this long and difficult process. It can be concluded that, at present, at national level, the involvement and mobilization of the community in the process of selective collection of solid waste is deficient, illustrating a faulty waste management, requiring immediate action by decision makers by initiating projects and implementation of public policy measures to help improve the current situation.

In this sense, the research activity has a fundamental role.

\section{REFERENCES}

Ciocotisan, B., (2020). Eurostat: Romania generated 272 tons of municipal waste per person in 2018, in 1asig.ro. Retrieved on August 15, 2020, from: https://www.1asig.ro/EurostatRomania-a-generat-272-tone-de-deseuri-municipale-per-persoana-in-2018-articol-3,10263139.htm

Colectare selectivă. (n.d.). In Wikipedia. Retrieved August 8, 2020, from https://ro.wikipedia.org/wiki/Colectare selectiv\%C4\%83

European Commission, DG Environment. (2010). Analysis of the evolution of waste reduction and the scope of waste prevention - Final report. Retrieved on August 20, 2020, from https://ec.europa.eu/environment/waste/prevention/pdf/report_waste.pdf

European Commission, Reprezentanța în România, (n.d.). (2018). Obiectiv 2030: materiale plastice recuperabile/reciclabile 100\%. Retrieved on September 21, 2020, from https://ec.europa.eu/romania/news/20181601_strategie_europeana_materiale_plastice_ro

European Commission (2019). Communication from the Commission to the European Parliament, the Council, the European Economic and Social Committee and the Committee of the Regions. Bruxelles. $\quad$ Retrieved August 23, 2020, from 
https://ec.europa.eu/transparency/regdoc/rep/1/2019/RO/COM-2019-149-F1-RO-MAIN-PART1.PDF

Eurostat. (2016). Statistici privind deșeurile. Retrieved on September 21, 2020, from https://ec.europa.eu/eurostat/statistics-explained/index.php?title=Waste_statistics/ro.

Eurostat. (2020). Generation of waste by waste category, hazardousness and NACE Rev. 2 activity[env_wasgen]. Retrieved on September 21, 2020, from https://appsso.eurostat.ec.europa.eu/nui/show.do?dataset=env wasgen\&lang=en

Ministry of Environment and Sustainable Development. (2008). Strategia Naţională pentru Dezvoltare Durabilă a României Orizonturi 2013-2020-2030, Retrieved August 19, 2020, from http://www.mmediu.ro/beta/domenii/dezvoltare-durabila/strategia-nationala-a-romaniei2013-2020-2030/

Ripeanu, A. (2019, October, 16). Metode inovative de reciclare într-o lume în care colectarea selectivă a deșeurilor este o problemă in Perol.ro. Retrieved on October 01, 2020, from https://perol.ro/metode-inovative-de-reciclare-intr-o-lume-in-care-colectarea-selectiva-adeseurilor-este-o-problema/

Teodor, C., Trică, C L, Ignat, R., \& Drăcea, R. M. (2020). Good Practices of Efficient Packaging Waste Management. Amfiteatru Economic, 22(55), 937-953. Retrieved in August 25, 2020, from: https://www.amfiteatrueconomic.ro/temp/Article_2941.pdf

Tुurcan, G. (2019). Ethical aspects of the circular economy. Collection of scientific papers of the International Scientific Conference "Competitiveness and innovation in the knowledge economy", 21. Chisinau. e-ISBN 978-9975-75-968-7

Vermeșan, H., Mangău, A., \& Tiuc, A. (2020). Perspectives of Circular Economy in Romanian Space, Sustainability, special issue Circular Economy and Sustainable Strategies, 12(17), Retrieved on August 20, 2020, from https://www.mdpi.com/2071-1050/12/17/6819/htm 